\title{
DIGLOSSIA AND MULTILINGUALISM: A LANGUAGE CHALLENGE IN MACHAKOS SUBORDINATE COURTS
}

\author{
Emma Mwende Mulwa \\ Teacher of English Language and Literature in English, \\ The Machakos Girls' High School, \\ Machakos, Kenya
}

\begin{abstract}
:
Human beings can acquire as many languages as they come in contact with, and utilize them as it is permissible and applicable in a society. This article seeks to explore language needs among the participants in the subordinate courts in Machakos County, in an attempt to figure out if those needs are attended to by the current language policy in the courts. The article is an extraction from a PhD study. The proficiency with which some of the participants use the languages they know makes their cases attract unjust ruling. To elicit information on the language needs they have during court proceedings, interviews, questionnaires and nonparticipant observation were used to carry out a descriptive qualitative and quantitative research. Thirteen defendants and defense counsels, thirteen witnesses and eighteen members of the public took the questionnaires, while three magistrates and clerks/interpreters attended the interviews. The researcher observed the proceedings. After triangulation of the data collected, the findings were that, the participants use the official languages, English and Kiswahili or interpretation of their indigenous languages. This is detrimental to their cases because they are not proficient in the languages. The interpreter is incapable of expressing the sentiments of the accused and the witnesses appropriately. Court participants need to use languages they know best in order to express their issues precisely. This article therefore recommends the use of a language that an accused or a witness cognizes. It also recommends the elevation of indigenous languages to official status within their area of dominance.
\end{abstract}

Keywords: diglossia, multilingualism, language needs, indigenous languages, human rights

\section{Introduction}

Language enables harmonious communication. Most communities and individuals today are multilingual, meaning that there is use of more than one language, either by an individual or a group of speakers. The society in many cases is in a diglossic situation where it has high and low languages, that is, formal and informal languages. Diglossia, in this article is a situation in which two or more languages are used by a single language community, with high (in this case, English)

i Correspondence: email mwendemulwa@gmail.com 
or low (the national language and indigenous languages, in this case, Kiswahili and Kikamba) functionality within its domains. In some cases, this can be to its disadvantage or that of its individual members. It amounts to social conflict which eliminates unification among members (Al- Brri, Bani-Yaseen, and Al-Zu'bi, 2015). Language problems are therefore bound to arise and manifest themselves in the competence and proficiency to use a language within different domains. Language management therefore attempts to solve these language problems (Nekvapil, 2012). The functionality of a language within a societal domain, in this case, the subordinate courts, demands prominence.

Language diglossia is brought about by the contact between languages and emergence of new other languages and dialects which leads to losing some of their original characteristics and qualities as well as moving away from mother tongues. It is also created by a country's language policy. Diglossia in a multilingual community necessitates code-switching (Al- Brri, et al, 2015) and code-mixing for some individuals to express themselves adequately. The need to be heard and understood impetrates the speaker to choose a language they are competent in. In this context, language needs refer to the purpose for which a language will be required. It may be to pass on information, to warn, to educate or even, in the legal context, to understand what one is being accused of and defend themselves (Mulwa, 2020).

There are challenges in justice attainment in a diglossic and multilingual society. Although the country has a language policy assigning English to formal domains such as in subordinate courts, and even allowing the use of Kiswahili and mother tongues but through interpreting, a number of the citizens fail to express themselves adequately because they have to use languages they are not competent in or use an incompetent interpreter. There is therefore the feeling of a linguistic insecurity, in a varied literacy developed community that is in search for educational and socioeconomic success. This study was motivated by the realisation that indigenous languages are widely used, particularly in courts, but they are not used appropriately for some of the users do not know them well. They are therefore misused. There is the need to minimise injustices in the judicial system arising from linguistic issues by correcting this situation.

This study hopes to identify individuals' language needs during subordinate court proceedings and the challenges that come with a multilingual society in the diglossic situation. It is an attempt to bring to attention that having and using a formal language in formal situations does not render judgments just, the society has members that can only use the informal languages and carry out fair proceedings and ultimately a just ruling.

Depending on the location, context and the interlocutors' social and cultural backgrounds, different languages are preferred to enable communication irrespective of competence and proficiency in their language use patterns. Efficient communication is enabled by; inter alia, their language choice. Kenya is a member state of United Nations Educational, Scientific and Cultural Organization (UNESCO), which held a conference on adult education that resolved that member states should raise awareness about prejudice and discrimination in society; that all indigenous people and nomadic people have a right of access to all levels and forms of state education, and the right to enjoy their own cultures and to use their own languages (UNESCO 1997:28, Ogechi, 
2003:286). This is promoted by mother tongues. To this effect, participants in a court should be able to use their mother tongues.

Kenya is multilingual; both at societal and individual level (Muaka, 2011). The majority of the tribes in Kenya have members living in the large cities where they speak English and Kiswahili, and still retain some of their native culture and ethnic languages. But as it is in a country, most of the people live in the rural and semi-rural areas. Among the languages spoken in Kenya, both English and Kiswahili serve as official languages, while Kiswahili doubles as a national language and an official language (Muaka, 2011; Central Intelligence Agency (CIA), 2015).

\section{Literature Review}

In Kenya, the language policy is such that English is the formal language while Kiswahili is less formal compared to English, but mother tongue is informal. When a country makes its language policies, it is expected to include all its citizens. But at times, it happens that individuals become too selfish and mean with tolerance for those with lower literacy. "...when a language policy development is in harmony with equity, it will promote measures of tackling the avoidable factors that fuel inequalities so that no individuals or regions are denied the chance to benefit" (Kioko 2013:26). It is necessary to consider the uniqueness of a community and its languages and endeavor to permit the participation of each member.

Jagodic (2011:8) explains with reasons why language planning is important to a country. He says that it is important because it brings about unification in communication among the citizens. He asserts that through language planning, a country is able to deal with modernisation that has come with new technology and modern education. He also adds that linguistic rights can only be exercised when there is democracy which is achievable through language planning. He concludes his points by claiming that verbal or written communication in a country is improved through language planning. That this unification can also be done regionally so that it does not have to be a national language, but a constituent's language.

In order to have a stable diglossia, perhaps unintended, the early sociolinguists had a consensus view that a major European language (French or English) should be used for formal and specialised domains, while local languages could serve other functions (Ricento, 2006:13). The idea may have worked then, but there are detrimental results of this kind of an arrangement. There was the effect of lowering the status and relegating the domains of indigenous languages to local uses, while elevating the status and extending the domains of former colonial languages of political and elite educational sectors, helping to perpetuate the stratified, class-based structures of the colonial era (Ricento, 2006:13). With today's general development in the economy, social standards of living, education and political status, language is no longer based on colonial structures but on the social setting. The people comprising a society are of different educational backgrounds with different political aspirations and living standards, yet sharing a dominant 'European' language and a local language.

Diglossia in developing countries was criticised as "an ideological naturalisation of sociolinguistic arrangements" (Woolard \& Schieffelin, 1994) perpetuating linguistic and related 
social inequalities (Ricento, 2006:13). It was the case then and still is as Ndlovu (2013: 92) argues that in cases where speakers of officially minority languages have low ethno-linguistic vitality and awareness as a result of linguistic heterogeneity and fragmentation, which foster language shifts, language accommodation and diglossia, they prefer to function mostly in the politically dominant languages. English therefore has taken this position in most countries, and specifically in Kenya. Many parents have shifted from using their indigenous languages at home to using English because English is the official language; it is used in schools as the language of instruction and examination, it is the language for trade and economic advancement and international relations (Muthwii, 2007). Although the indigenous languages are dominant in the counties, they are no match for English as they are not given substantial value. English has been accommodated, and co-exists with indigenous languages. Ndlovu (2013:95) refers to it as marked bilingualism; which is a result of being comfortable in a second language due to lack of communicative needs in the home language. However, not every person has the ability to use this second language even when they have gone to school. Others know only their first languages.

According to the census of Kenya as at July 2014 estimates, the country has a total population of about $45,010,056$, of which $24 \%$ is urban population and $76 \%$ is rural population. Literacy, the ability to read, falls at $87.4 \%$ of the total population as recorded in the World Factbook of the Central Intelligence Agency (CIA) 2015. There is therefore a low level of urbanisation, but a high level of literacy. This could mean that the dominant languages and their speech communities would result in heterogeneity and multilingualism. This includes Machakos County, where the dominant local language, Kikamba, is threatened by literacy in English and Kiswahili. The county relies on what the country has laid down for its courts. If Kenyans aspire to be part of the increasingly democratic world, then everybody should have a chance to participate. Everybody includes the elite, the highly and lowly educated, those in cities and rural areas, members of numerically large and small ethnic groups, the handicapped, monolinguals and bilinguals and the youth in the spirit of devolution (Ogechi, 2003).

The subordinate courts are meant to serve everybody (Mbote \& Akech, 2011). However, there seems to be a gap in terms of communication and interpretation. Poor or lack of communication is the result of lack of a language policy that accommodates everybody during court proceedings. English, which is the main language of the court (Muaka, 2011), is better known by the elite only. Interpreters may not interpret correctly. Conversations in court are therefore limited to the elite. The illiterate keep quiet and watch until such a time the interpreter will be required to interpret. Odhiambo, Kavulani and Matu (2013) found that illiterate people are given interpreters who, in most cases, are not competent in the use of indigenous languages.

An average Kenyan speaks at least three languages, English, Kiswahili and an indigenous language (Muaka, 2011). Chapter 49 of the Constitution of Kenya stipulates that an arrested person has the right to be informed promptly in a language that he or she understands, of the reason for the arrest, the right to remain silent and the consequences of not remaining silent. It also stipulates that the accused persons have the right to have an interpreter without payment if the accused person cannot understand the language used at the trial. It further stipulates that if the accused person requires information, such information shall be given in a language that the 
person understands (Malan, 2016). Although these stipulations are made, the question is how well this use of a language that the accused person can understand is implemented, if it is at all. Is the interpretation done accurately, and is an interpreter readily available and conversant with the indigenous language?

The Advisory Panel of Eminent Commonwealth Judicial Experts, which was called upon to advise the Constitution of Kenya Review Commission (CKRC) on constitutional reforms regarding the Kenya judiciary concluded that:

"... as presently constituted, the Kenyan judicial system suffers from a serious lack of public confidence and is generally perceived as being in need of fundamental structural reform. It is our considered view that strong measures are necessary for Kenya to achieve an independent and accountable judiciary, capable of serving the needs of the people of Kenya by securing equal justice and the maintenance of the rule of law under a new constitutional order." (Mbote \&Akech, 2011:48).

The Kenyan Judiciary has a crisis of confidence. A number of factors, including poverty, gender, religion, lack of knowledge of their rights, corruption, poor governance, tribalism, nepotism, illiteracy, discrimination, cumbersome process, courts that are far, fear and culture, are some of the identified causes of this lack of confidence in the judicial system (Mbote and Akech, 2011:161). Language has not clearly been captured well in the study by Mbote and Akech (2011) among others, instead they discuss about culture in general, and therefore this study attempts to fill the gap.

In conclusion, lack of a clear language policy that accommodates everybody during a court proceeding leading to poor or lack of communication can be solved by the creation of a policy that accommodates the needs, uses and preferences of a language by the language user.

\subsection{Theoretical Framework}

This study is grounded on the language management theory (LMT) and the linguistic human rights paradigm (LHRP). Language management theory was developed by Jiri Neustupny, (1978) in his work on "Outline of a Theory of Language Problems". He bases language planning on the theory of language problems caused by particular interactions. The language planning activity takes a process which begins with identification of a language problem in an individual interaction, followed by adoption of a measure by the institution, then implementation of that measure to correct the problem. Mwaniki (2011:254) defines language management as a discipline, and as an organised body of knowledge that preoccupies itself with a particular set of questions with regard to language in society and language and society. Hence, the identification of language problems and challenges among participants in subordinate courts in Machakos. Linguistic human rights is about the rights to one's own language in legal, administrative and judicial acts which can be human or civil. The proponents of LHRP include OHCHR (2017), Skutnubb-Kangas and Philipson (eds) (2017), among others. 


\section{Material and Methods}

The study took a language management theoretical perspective. It is a descriptive survey of language needs and use in the interactive dynamics of subordinate court's proceedings. Although the larger study, "Language management in relation to language needs, uses and preferences in subordinate courts: a case study of Machakos County", utilized interviews, questionnaires and nonparticipant observation, with a total of fifty two respondents including magistrates, witnesses, clerks or interpreters and members of the public, and a triangulation of the qualitative and quantitative data collected, this article has narrowed down to the questionnaires on language needs and use only. The items in the questionnaire included; the level of understanding when instructed or conversing in English, Kiswahili, Mixed Languages, Mother Tongues or Sign language, the frequency with which the respondents use the above mentioned languages in the subordinate courts, and the frequency with which the respondents wished they could use mother tongues in order to enable a better communication in the courts.

The target population for this study constituted participants in the court chambers. Purposive sampling and convenience sampling enabled the researcher to capture only those that were present at the court proceedings and at the time scheduled for the hearing.

Questionnaires were administered to thirteen witnesses and thirteen defendants/defense counsels, as well as eighteen members of the public as shown in table one below. The researcher administered questionnaires immediately after the court proceedings to enable the researcher to capture those that participated in the court proceedings before they left the court premises.

Some of the respondents filled the questionnaires there and then while others carried them away to fill them up and return them at an agreed later time. The questionnaires were sorted, coded and for some of the qualitative data, converted to numerical form, then entered into Statistical Package for Social Sciences (SPSS) tool for analysis. Simple descriptive and inferential statistics were generated from the analysis of the data. The analysis was then categorised and displayed in tables.

Table 1: Demographic profile of the respondents

\begin{tabular}{|l|l|c|c|}
\hline \multirow{5}{*}{ Factors } & Descriptors & \multicolumn{2}{|c|}{ Total } \\
\hline \multirow{5}{*}{ Gender } & & Number & $\%$ \\
\hline \multirow{5}{*}{ Age group } & Male & 33 & 75.0 \\
\cline { 2 - 3 } & Female & 11 & 25.0 \\
\hline & $19-27$ years & 21 & 47.7 \\
\hline & $28-36$ years & 10 & 22.7 \\
\hline & $37-45$ years & 7 & 15.9 \\
\hline & $46-54$ years & 3 & 6.8 \\
\hline & $55-63$ years & 2 & 4.5 \\
\hline \multirow{5}{*}{ Education level } & 64 and more & 1 & 2.3 \\
\hline & Never went to school & - & - \\
\cline { 2 - 3 } & Primary school drop-out & 3 & 6.8 \\
\cline { 2 - 3 } & Completed primary school & 5 & 11.4 \\
\hline & Secondary school drop-out & 1 & 2.3 \\
\cline { 2 - 4 } & Completed secondary school & 16 & 36.4 \\
\hline
\end{tabular}


DIGLOSSIA AND MULTILINGUALISM: A LANGUAGE CHALLENGE IN MACHAKOS SUBORDINATE COURTS

\begin{tabular}{|l|l|c|c|}
\hline & Tertiary level & 19 & 43.2 \\
\hline \multirow{2}{*}{ Brought up } & In town - urban & 10 & 22.7 \\
\cline { 2 - 5 } & In village - rural & 34 & 77.3 \\
\hline Overall & & 44 & 100.0 \\
\hline
\end{tabular}

Source: Field data, 2017.

\section{Results and Discussion}

How the respondents understand determine their language needs in order to communicate effectively and efficiently. Table 2 presents their choices in terms of where the respondents were brought up. Cumulative responses were elicited as a respondent identified several languages at a time, hence over $100 \%$ feedbacks. The majority of those respondents from the rural areas understand mother tongues better than those brought up in urban areas, $72.2 \%$ against $42.9 \%$. Those that understand English are more in town than in rural areas at $71.4 \%$ against $43.8 \%$. The same percentage of 71.4 that understands English in town is the same that understands Kiswahili, but in the rural areas there are more at 50\% compared to $43.8 \%$. Although most of the respondents in this study were from rural areas, it is also clear that most of those that understood all the languages extremely well except for mother tongues were those brought up in town. No respondent who was brought up in town that claimed not to understand English, Kiswahili, mixed languages or mother tongues at all. From those brought up in rural areas, $12.5 \%$ claimed not to understand English at all. These are probably those people that did not attend school since primary school education in Kenya was not free and compulsory like it is today. Others have lost their competence due to lack of practice and probably old age. This means that English may not be the best language for people in the rural areas. It may not meet their needs.

Table 2: The level of understanding when instructed or conversing in any of the various languages

\begin{tabular}{|c|c|c|c|c|c|c|c|}
\hline \multirow{2}{*}{ Factors } & \multirow{2}{*}{ Language } & \multicolumn{5}{|c|}{$\begin{array}{l}\text { How well do you understand when instructed to do something or have a } \\
\text { conversation in the given languages }\end{array}$} & \multirow{2}{*}{ Total } \\
\hline & & $\begin{array}{l}\text { Extremely } \\
\text { well }\end{array}$ & $\begin{array}{l}\text { Very } \\
\text { well }\end{array}$ & Well & $\begin{array}{c}\text { Fairly } \\
\text { well }\end{array}$ & $\begin{array}{l}\text { Not } \\
\text { at all }\end{array}$ & \\
\hline \multicolumn{8}{|c|}{ Brought up } \\
\hline \multirow{5}{*}{$\begin{array}{l}\text { In } \\
\text { Town - } \\
\text { urban }\end{array}$} & E & $5(71.4 \%)$ & $1(14,3 \%)$ & $1(14,3 \%)$ & & & $7(100 \%)$ \\
\hline & $\mathrm{K}$ & $5(71.4 \%)$ & $1(14,3 \%)$ & $1(14,3 \%)$ & & & $7(100 \%)$ \\
\hline & ML & $1(14,3 \%)$ & $2(28.6 \%)$ & $3(42.9 \%)$ & $1(14,3 \%)$ & & $7(100 \%)$ \\
\hline & MT & $3(42.9 \%)$ & $1(14,3 \%)$ & $1(14,3 \%)$ & $2(28.6 \%)$ & & $7(100 \%)$ \\
\hline & SL & $1(14,3 \%)$ & & & $2(28.6 \%)$ & $4(57.1 \%)$ & $7(100 \%)$ \\
\hline Total & & $15(42.9 \%)$ & $5(14.3 \%)$ & $6(17.1 \%)$ & $5(14.3 \%)$ & $4(11.4 \%)$ & $35(100 \%)$ \\
\hline \multirow{5}{*}{$\begin{array}{l}\text { In } \\
\text { Village - } \\
\text { rural }\end{array}$} & $\mathrm{E}$ & $7(43.8 \%)$ & $4(25 \%)$ & $2(12.5 \%)$ & $1(6.3 \%)$ & $2(12.5 \%)$ & $16(100 \%)$ \\
\hline & K & $8(50 \%)$ & $5(31.3 \%)$ & $3(18.8 \%)$ & & & $16(100 \%)$ \\
\hline & ML & $1(6.3 \%)$ & $3(18.8 \%)$ & $7(43.8 \%)$ & $5(31.3 \%)$ & & $16(100 \%)$ \\
\hline & MT & $13(72.2 \%)$ & $2(11.1 \%)$ & $2(11.1 \%)$ & $1(5.6 \%)$ & & $18(100 \%)$ \\
\hline & SL & & & & $5(31.3 \%)$ & $11(68.8 \%)$ & $16(100 \%)$ \\
\hline Total & & $29(35.4 \%)$ & $14(17.1 \%)$ & $14(17.1 \%)$ & $12(14.6 \%)$ & $13(15.9 \%)$ & $82(100 \%)$ \\
\hline
\end{tabular}

E-English, K-Kiswahili, ML-Mixed Languages, MT-Mother Tongue, SL-Sign Language 
This means that when the court insists on using English, they do not meet all the people's needs and especially if they come from the rural areas. Generally, the majority of those brought up in the rural areas understand mother tongues better than those brought up in urban areas. It is also clear that most of those that understood all the languages extremely well except mother tongues were brought up in towns. This could be because of constant practice in the language use since in towns the national and official languages are commonly used for unity purposes. No respondent brought up in towns claimed not to understand English, Kiswahili, mixed languages or mother tongues at all. In the past, people were keen on using their mother tongues. In fact, they were being taught and used it in schools and it is supposed to be the same today as per the education policy. So, the parents that went through this period may not have problems using mother tongues with their children. It cannot be said that most people can communicate proficiently in any of the languages. If anything, one language is not sufficient for an individual. $5.9 \%$ of the respondents do not understand English at all. The fact that this is an official language which is highly used in court means that a big number of participants are negatively affected when instructions are given in English in court. Their linguistic needs are compromised whenever English is used. 44.1\% of the respondents do not understand at all when instructed in sign language. This means that the hearing-impaired are quite disadvantaged when they need to use their sign language, for very few can communicate in them.

The second question asked how often the respondents use the various languages in the subordinate courts. Not all questions were answered by all the respondents, hence the difference in totals.

Since courts are supposed to allow the use of mother tongues but with interpretation, as well as the use of the official languages, mixing them all would also be possible. This means whichever language is used at will is also expected to serve their needs. $34.8 \%$ of the respondents use English always, 30.4\% uses it quite often, $26.1 \%$ use it often, $4.3 \%$ use it less often and another $4.3 \%$ do not use it at all. Half of the witnesses always use it and only $8.3 \%$ use it less often. A quarter of the members of the public always use it while a half uses it quite often and another quarter uses it often. This means that all the members of the public are constantly in use of the English language. However, $14.3 \%$ of the defendants and defense counsels do not at all use English, and only another $14.3 \%$ use English always. The majority (42.9\%) of the defendants and defense counsels use English often. This is a pointer to the fact that since this is the most important category in court, English may not be a comfortable language for them to use. Though English is a favourite language in courts because it is always and quite often used as the language of court, a small percentage does not at all use it.

$43.5 \%$ of the respondents use Kiswahili always, $26.1 \%$ uses it quite often, $21.7 \%$ use it often and $8.7 \%$ use it less often. Nobody responded to not using it at all. Kiswahili is therefore highly used. $4.2 \%$ of the respondents always use mixed languages in court, $25 \%$ quite often use mixed languages, $29.2 \%$, which is the highest percentage, often use mixed languages, and another $29.2 \%$ use them less often. $12.5 \%$ do not mix languages at all in court. $8.7 \%$ of the respondents always use mother tongues in subordinate courts, another $8.7 \%$ use them quite often, $13 \%$ often, making a total of $30.4 \%$ that used them with a reasonably high magnitude. A bigger percent of $43.5 \%$ use it less often in court and $26.1 \%$ do not use it at all. 
Table 3: The frequency with which the given languages are used in subordinate courts

\begin{tabular}{|c|c|c|c|c|c|c|}
\hline \multirow[b]{2}{*}{ Category } & \multicolumn{5}{|c|}{ How often you use these languages in subordinate court } & \multirow[b]{2}{*}{ Total } \\
\hline & Always & $\begin{array}{l}\text { Quite } \\
\text { often }\end{array}$ & Often & $\begin{array}{l}\text { Less } \\
\text { often }\end{array}$ & $\begin{array}{l}\text { Not } \\
\text { at all }\end{array}$ & \\
\hline \multicolumn{7}{|l|}{ English } \\
\hline Defendant/Defense Counsel & $1(14.3 \%)$ & $2(28.6 \%)$ & $3(42.9 \%)$ & & $1(14.3 \%)$ & $7(100 \%)$ \\
\hline Member of Public & $1(25.0 \%)$ & $2(50.0 \%)$ & $1(25.0 \%)$ & & & $4(100 \%)$ \\
\hline Witnesses & $6(50.0 \%)$ & $3(25.0 \%)$ & $2(16.7 \%)$ & $1(8.3 \%)$ & & $12(100 \%)$ \\
\hline Total & $8(34.8 \%)$ & $7(30.4 \%)$ & $6(26.1 \%)$ & $1(4.3 \% \%)$ & $1(4.3 \%)$ & $23(100 \%)$ \\
\hline \multicolumn{7}{|l|}{ Kiswahili } \\
\hline Defendant/Defense Counsel & $3(42.9 \%)$ & $2(28.6 \%)$ & $1(14.3 \%)$ & $1(14.3 \%)$ & & $7(100 \%)$ \\
\hline Member of Public & $1(25.0 \%)$ & $1(25.0 \%)$ & $1(25.0 \%)$ & $1(25.0 \%)$ & & $4(100 \%)$ \\
\hline Witnesses & $6(50.0 \%)$ & $3(25.0 \%)$ & $3(25.0 \%)$ & & & $12(100 \%)$ \\
\hline Total & $10(43.5 \%)$ & $6(26.1 \%)$ & $5(21.7 \%)$ & $2(8.7 \%)$ & & $23(100 \%)$ \\
\hline \multicolumn{7}{|l|}{ Mixed Language } \\
\hline Defendant/Defense Counsel & & & $5(62.5 \%)$ & $2(12.5 \%)$ & $1(12.5 \%)$ & $8(100 \%)$ \\
\hline Member of Public & & $1(25.0 \%)$ & $1(25.0 \%)$ & $2(50.0 \%)$ & & $4(100 \%)$ \\
\hline Witnesses & $1(8.3 \%)$ & $5(41.7 \%)$ & $1(8.3 \%)$ & $3(25.0 \%)$ & $2(16.7 \%)$ & $12(100 \%)$ \\
\hline Total & $1(4.2 \%)$ & $6(25.0 \%)$ & $7(29.2 \%)$ & $7(29.2 \%)$ & $3(12.5 \%)$ & $24(100 \%)$ \\
\hline \multicolumn{7}{|l|}{ Mother Tongue } \\
\hline Defendant/Defense Counsel & $1(14.3 \%)$ & $1(14.3 \%)$ & $1(14.3 \%)$ & $1(14.3 \%)$ & $3(42.9 \%)$ & $7(100 \%)$ \\
\hline Member of Public & & & $1(25.0 \%)$ & $2(50.0 \%)$ & $1(25.0 \%)$ & $4(100 \%)$ \\
\hline Witnesses & $1(8.3 \%)$ & $1(8.3 \%)$ & $1(8.3 \%)$ & $7(58.3 \%)$ & $2(16.7 \%)$ & $12(100 \%)$ \\
\hline Total & $2(8.7 \%)$ & $2(8.7 \%)$ & $3(13.0 \%)$ & $10(43.5 \%)$ & $6(26.1 \%)$ & $23(100 \%)$ \\
\hline \multicolumn{7}{|l|}{ Sign Language } \\
\hline Defendant/Defense Counsel & & & $1(14.3 \%)$ & $1(14.3 \%)$ & $5(71.4 \%)$ & $7(100 \%)$ \\
\hline Member of Public & $1(25.0 \%)$ & & & $2(50.0 \%)$ & $1(25.0 \%)$ & $4(100 \%)$ \\
\hline Witnesses & & $1(9.1 \%)$ & & $1(9.1 \%)$ & $9(81.8 \%)$ & $11(100 \%)$ \\
\hline Total & $1(4.5 \%)$ & $1(4.5 \%)$ & $1(4.5 \%)$ & $4(18.2 \%)$ & $15(68.2 \%)$ & $22(100 \%)$ \\
\hline
\end{tabular}

This shows that a good number of users of the courts actually do use the mother tongue, a nonofficial language. Sign language is not a language for everybody, but $4.5 \%$ always use it, another $4.5 \%$ quite often use it, yet another $4.5 \%$ often use it. $18.2 \%$ use it less often and the majority, $68.2 \%$, does not at all use it. Those that always use sign language may be the deaf and dump and quite often use it may be because they are in constant contact with other deaf and dump people. This being a language of the deaf and dump may not be considered the main challenge until the courts receive a person with such disability to serve. Nevertheless, although they are a minority group, these people have the right to be considered. Otherwise, the majority of the respondents do not at all use sign language.

The more a language is used shows how people's needs are better expressible in that particular language. Although the majority of respondents use mother tongues less often (44\%), they still use them and the number increases to $73.9 \%$ when those who use them quite often and always are included. Everybody uses Kiswahili one way or the other. So, it is a very popular language; only it is not the language of the court. The reason why a high percentage of participants use English could be because the majority of them are defendants, probably counsels, so they have to use it. In many cases, a word here or there has to be understood the 
way the speaker wants it if it is expressed in a particular language, and hence the high percentage of mixing the languages. Those who do not mix probably know only one language. Sign languages are not understood by many therefore not used; hence the high percentage of those who do not use them. From this presentation, big numbers of court users will use English, Kiswahili, mother tongue and mixed languages quite often to express their needs. They are multilingual and hence the mixing of the languages. The situation is such that there are official languages and indigenous languages at play during a court proceeding.

In the last question, the researcher sought to find out the frequency with which the respondents wished mother tongues use to allow a better communication in the courts. Better communication and understanding are the core reasons for speech in the first place. A mother tongue is expected to be the easiest language to use, especially for people from the rural areas and the aged.

Table 4: The frequency with which participants would wish to use mother tongue in court

\begin{tabular}{|c|c|c|c|c|c|c|}
\hline & \multicolumn{5}{|c|}{ How often you wish Mother tongue to be used in courts } & \multirow[b]{2}{*}{ Total } \\
\hline & Always & $\begin{array}{l}\text { Very } \\
\text { often }\end{array}$ & Often & $\begin{array}{l}\text { Less } \\
\text { often }\end{array}$ & $\begin{array}{l}\text { Not } \\
\text { at all }\end{array}$ & \\
\hline \multicolumn{7}{|l|}{ Category } \\
\hline Defendant/Defense Counsel & $2(25.0 \%)$ & $2(25.0 \%)$ & $3(37.5 \%)$ & $1(12.5 \%)$ & & $8(100 \%)$ \\
\hline Member of Public & & $2(25.0 \%)$ & $2(25.0 \%)$ & $2(50.0 \%)$ & & $4(100 \%)$ \\
\hline Witnesses & $1(7.7 \%)$ & $4(30.8 \%)$ & $5(36.5 \%)$ & $2(15.4 \%)$ & $1(7.7 \%)$ & $13(100 \%)$ \\
\hline Total & $3(12.0 \%)$ & $7(28.0 \%)$ & $9(36.0 \%)$ & $5(20.0 \%)$ & $1(4.0 \%)$ & $25(100 \%)$ \\
\hline \multicolumn{7}{|l|}{ Age group } \\
\hline $19-27$ years & & $3(27.3 \%)$ & $3(27.3 \%)$ & $4(36.4 \%)$ & $1(9.1 \%)$ & $11(100 \%)$ \\
\hline $28-36$ years & $1(16.7 \%)$ & $1(16.7 \%)$ & $4(66.7 \%)$ & & & $6(100 \%)$ \\
\hline $37-45$ years & $1(25.0 \%)$ & $2(50 \%)$ & $1(25.0 \%)$ & & & $4(100 \%)$ \\
\hline $46-54$ years & $1(50.0 \%)$ & & $1(50.0 \%)$ & & & $2(100 \%)$ \\
\hline 55 - 63 years & & $1(50.0 \%)$ & & $1(50.0 \%)$ & & $2(100 \%)$ \\
\hline Total & $3(12.0 \%)$ & $7(28.0 \%)$ & $9(36.0 \%)$ & $5(20.0 \%)$ & $1(4.0 \%)$ & $25(100 \%)$ \\
\hline \multicolumn{7}{|l|}{ Education level } \\
\hline Primary School drop-out & & & $3(100 \%)$ & & & $3(100 \%)$ \\
\hline Completed primary school & & & $1(100 \%)$ & & & $1(100 \%)$ \\
\hline Completed secondary school & $1(11.1 \%)$ & $4(44.4 \%)$ & & $3(33.3 \%)$ & $1(11.1 \%)$ & $9(100 \%)$ \\
\hline Tertiary level & $2(16.7 \%)$ & $3(25.0 \%)$ & $5(41.7 \%)$ & $2(16.7 \%)$ & & $12(100 \%)$ \\
\hline Total & $3(12.0 \%)$ & $7(28.0 \%)$ & $9(36.0 \%)$ & $5(20.0 \%)$ & $1(4.0 \%)$ & $25(100 \%)$ \\
\hline \multicolumn{7}{|l|}{ Brought up } \\
\hline In Town -urban & $1(14.3 \%)$ & $2(28.6 \%)$ & $4(57.1 \%)$ & & & 7 (100) \\
\hline In Village-rural & $2(11.1 \%)$ & $5(27.8 \%)$ & $5(27.8 \%)$ & $5(27.8 \%)$ & $1(5.6 \%)$ & $18(100 \%)$ \\
\hline Total & $3(12.0 \%)$ & $7(28.0 \%)$ & $9(36.0)$ & $5(20.0 \%)$ & $1(4.0 \%)$ & $25(100 \%)$ \\
\hline
\end{tabular}

$12 \%$ of the respondents wished the mother tongue could be used always, $28 \%$ wished it could be used very often, $36 \%$ wished it could be used often, while $20 \%$ wished it could be used less often and $4 \%$ wished it could not at all be used. A bigger percentage responded positively to this question. That is, those that wished that mother tongues should be used always, very often and often, made a total of $76 \%$, while the rest $24 \%$ responded negatively. They wished it used less often and not at all. This response means that mother tongues are understood better than the 
other languages by many people; and if they use them in court, they would be better served because there will be better communication. Only $4 \%$ of the respondents and from the youngest age group wish mother tongues not to be used in court. This could be because the young generation is generally not in favour of their mother tongues. All the others even if they wish it less often used, still acknowledge and wish that it be used. The group that has completed secondary school is the only one that has $4 \%$ wishing that mother tongues not be used at all, and $20 \%$ wishing negatively that they be used less often. Otherwise, the majority of the members of this group wished for mother tongues to be used. Those that are more educated are more encouraged to use mother tongues than the less educated. As it is, those that completed secondary school and those at tertiary level wish to always and very often use mother tongues in court. Even with their knowledge of the other languages, they still wish for mother tongues. This shows that the age or the level of education do not matter much but more whether there is understanding and communication in seeking for justice. From where one was brought up, an attitude could have developed. Those wishing not to use their mother tongue are from the rural areas; yet those brought up in urban areas all wish to use their mother tongues in court. In a nutshell, those that did not at all wish mother tongues used in subordinate courts constituted $4 \%$, and were witnesses aged 19-27 years that had completed secondary school and had been brought up in villages. This is probably the group of people that have low opinion and negative attitude towards their mother tongues, hence this reaction.

From the presentation and analysis of the data, mother tongues are the most understood and English the least understood. Mother tongues are used less often by the majority of the respondents in subordinate courts, while everybody somehow uses Kiswahili. Many participants use English, but because the majority of them are employees of the court, they have to. Most of the respondents wished mother tongues would be used for better communication and understanding in subordinate courts. This way, language would meet people's needs. With this summary, it is clear that mother tongues meet people's needs better than English, while Kiswahili is a language people try to use to survive the ordeals of courts.

Language dominance is associated with bilingualism (and multilingualism), and can be defined as "the relationship between the competencies in the two languages" (Treffers-Daller, 2011:148). In this study language dominance is the language fluency by a majority in a bilingual community. Language ability is determined by the lexical knowledge and the variation within an individuals' lexical knowledge. According to Treffers-Daller (2011), oral fluency can be used to determine bilingual dominance. It is this oral fluency that is the key to identifying the main language of a community. The most common language should be the one used by the people in the area where it dominates. Mother tongue, Kikamba, is such a language in the Machakos County. At the same time, the official languages, English and Kiswahili, dominate in the courts.

Every country relies on their courts to accord justice. Those that require court settlements come from all walks of life, ranging from children to adults, the rich to the poor, the literate to the illiterate, the villagers to the town dwellers, the citizens to the immigrants, and the list is long. Language use in subordinate courts is not an easy topic of contention because the language of the court is traditionally English. But does it mean that all courts in the world use English? Definitely not. There is French, German, Italian and so on. Just because Kenya was colonised by 
Europeans does not mean that it must remain colonised even in their own places of justice. And because it is not possible to have only those with proficiency and competence in English in courts, the courts have employed the use of interpreters. The use of interpreters has been proven disastrous to the attainment of justice.

According to scholars, language needs refer to language resources and activities required by second language learners and adults in order to cope with different forms of communication (Council of Europe, 2018). In this study, language needs are the uses that are actually required or made in order to communicate in court. People will want mother tongues to argue their case and to be able to express themselves clearly. Others will require English, arguing that they are able to fit in the high social class. The communication situation is key in directing the choice of the language. Situations such as greeting, welcoming, arguing a case, thanking and saying goodbyes, refusal, general terms and conversations or specific careers are done in specific languages in order to achieve particular goals. It is for this reason that people in courts want to use their mother tongues or Kiswahili instead of other languages such as English.

Franks and Gessner (2013) pointed out that the language planning process should state the role of a language in the community. The process should as well state the language abilities one would like to see for themselves or the community. The courts have continued with the British system in the judiciary and so maintained the English language. The role played by the English language in this particular community is probably that of selective bias. It is very discriminative of the people that have not schooled much, the aged and those that have not been practicing its use. Gatitu (2009:1) says that English remains the language of power and elitism. It is therefore not a language for all. But again Ndlovu (2013) argues that there is marked bilingualism, which is using the second language because people are comfortable in it, for there is no need for communication in their home languages. There is a need for a language that is inclusive in court. Hence to counterpoise this challenge, all languages should be permissible for use.

\section{Recommendations}

The study made the recommendation that dominant indigenous languages in each county be made official. It also recommended defining the status of indigenous languages and foreign languages by the government enacting an indigenous language act that caters for various aspects of creation and implementation of a language policy. Policy makers need to clarify the place of official, national and official minority/indigenous language at a county level. It will also, through the constitution that promotes multilingualism, empower languages and guarantee linguistic human rights.

\section{Conclusion}

In conclusion, English is widely used in courts, but it is not the appropriate language to use. Accused persons and witnesses use English not because they know it, but because it is a prestigeladen language that enjoys high status or because they have to. When participants in court are 
challenged by a language, they turn to code-mixing and code-switching. This challenge then makes them to oscillate around the three languages: English, Kiswahili and mother tongue. The respondents understood extremely well when English or Kiswahili was used, followed by when mother tongue was used, then when mixed languages were used for respondents brought up in towns. It was different for those that were brought up in the rural areas. The majority understood extremely well when mother tongues were used, followed by when Kiswahili was used, then when English was used, and very few understood when mixed languages were used. The highest number did not understand English at all. Some wished to always use their mother tongues in subordinate courts.

Therefore, one's language needs in court will be fulfilled if they use a language they understand, of which the majority who were brought up in towns preferred Kiswahili and English, while the majority brought up in the villages preferred the mother tongue. The middle ground would be to allow the three languages. They would cater for everyone's needs whether they were from towns or villages. This is supported by the fact that people use these languages in their day to day activities and wish to continue using them even in court.

\section{Conflict of Interest Statement}

The author, Emma Mwende Mulwa certify that she has NO affiliation with or involvement in any organization or entity with any financial interest or non-financial interest in the subject matter or materials discussed in this manuscript.

\section{About the Author}

Emma is a teacher of English language and literature in English in Machakos High School and a sessional faculty in South Eastern Kenya University in Kenya. She is in the department of languages. She has attained her Doctor of Philosophy in linguistics, language and literature from University of South Africa (UNISA), a Master of Arts in linguistics from Kenyatta University and a Bachelor of Education (Arts) from Moi University. Her area of interest is language management and policy, multilingual society and the minority. She is a member of Language Association of East Africa (LAEA) and Journal of Research Information and implementation in Education (JRIIE).

\section{References}

Al- Brri Q, Bani-Yaseen A M, Al-Zu'bi A M, 2015. Diglossia among Students: The Problem and Treatment. Journal of Education and Practice 6:32. www.iiste.org. Accessed 2 June 2021

Central Intelligence Agency. 2016. The World Factbook. www.cia.gov/library/publication. Accessed 26 January 2020

Council of Europe, 2018. Linguistic Integration of Adult Migrants (LIAM): Language Needs. Council of Europe Portal, France. Democracy, ILMA. https://www.coe.int. Accessed 14 August 2019. 
Franks S, Gessner S, 2013. A Guide to Language Policy and Planning for B.C. First Nations Communities, Handbook Development Team. Brentwood Bay: First Peoples Cultural Council.

Gatitu K, 2009. Proteus. The Newsletter of the National Association of Judiciary Interpreters and Translators. Court Interpreting in Kenya: The Ideal and the Practice. Spring 2009:153(1) Washington, D.C.

Government of Machakos County, 2015.The Office Website of the Government of Machakos. www.machakosgovernment.com/... Accessed 6 March 2018

Jagodic D, 2011. Between Language Maintenance and Language Shift: The Slovenian Community in Italy today and tomorrow. Esuka - Jeful, 2(1):195-213

Kioko A, 2013. Language Policy and Practice in Kenya: Challenges and Prospects. In H. MacIlwraith (Ed.), Multilingual Education in Africa: Lessons from the Juba language-ineducation conference. 117-126. London: British Council

Malan K, 2016. Considering an Appropriate Language Policy for Judicial Proceedings in South Africa. https://www.droitslinguistiques.ca/ima language policy(injudicial proceedings. Accessed 11 November 2016

Mbote P M, Aketch M, 2011. Kenya: Justice Sector and Rule of Law. A Review by AfriMAP and the Open Society Initiative for Eastern Africa. Johannesburg: South Africa

Muaka L, 2011 Language Perception and Identity among Kenyan Speakers. In Selected Proceedings of the $40^{\text {th }}$ Annual Conference on African Linguistics, ed. Eyamba G Bokamba et al, 217-230 Someiville MA: Cascadilla Procedings Project. www.lingref.com, Accessed 5 August 2018

Mulwa E M, 2019. Language Management in Relation to Language Needs, Uses and Preferences in Subordinate Courts. A case Study of Machakos County. PhD Thesis. University of South Africa.

Muthwii J M, 2007. Language Planning and Literacy in Kenya: Living with Unresolved Paradoxes. In Luddicoat, A.J. (Ed.) Current issues in language planning. Multilingual Matters. Clevedon. 46-62

Mwaniki M M, 2011. Language Management in Africa: The Dialectics of Theory and Practice.

South African Linguistics and Applied Language Studies. 29(3):243-257

Ndlovu E, 2013. Mother Tongue Education in Official Minority Languages of Zimbabwe: A Language Management Critique. PhD Thesis; University of the Free State.

Nekvapil J, 2012. Some Thoughts on "Noting" in Language Management Theory and Beyond. Journal of Asian Pacific Communication 22(2):160-173.

Neustupny J V, 1978. Outline of a Theory of Language Problems. In J.V Neustupny (Ed.). PostStructural approaches to language: Language theory in Japanese context. Tokyo: University of Tokyo Press, pp 243-257,

Odhiambo K Kavulani C K, Matu P M, 2013. Court Interpreters View of Language Use in Subordinate Courts in Nyanza Province, Kenya. Theory and Practice in Language Studies, 3(6):910-918. 
Office of High Commission for Human Rights (ONCHR). 2017. Language Rights of Minorities: A practical Guide for Implementation. https://www.ohchr.org. Accessed 20 February 2017.

Ogechi N O, 2003. On Language Rights in Kenya. Nordic Journal of African Studies, 12(3):277295

Ricento T, 2006. An Introduction to Language Policy: Theory and Method. Oxford: Blackwell Publishing

Skutnubb-Kangas T, Phillipson R, (eds) 2017. Linguistic Human Rights, Past and Present. Language Human Rights. Overcoming Linguistic Discrimination. Sociology of Language Berlin \& New York: Mouton de Gruyter, 67:71-110.

Treffers-Deller, J. 2011. Operationalizing and Measuring Language Dominance. International Journal of Bilingualism. Language Dominance, Preference and Awareness: A case study of Two Multilingual Children in a Bilingual Community, 15:1-17.

UNESCO 1997. The agenda for the future. A booklet produced from the proceedings of CONFINTEA V: Fifth International Conference on adult education, 14-18 July 1997, Hamburg: UNESCO.

Woolard K A, Schieffelin B B, 1994. Language Ideology. Annual Review of Anthology. 23:55-82. 
Author(s) will retain the copyright of their published articles agreeing that a Creative Commons Attribution 4.0 International License (CC BY 4.0) terms will be applied to their work. Under the terms of this license, no permission is required from the author(s) or publisher for members of the community to copy, distribute, transmit or adapt the article content, providing a proper, prominent and unambiguous attribution to the authors in a manner that makes clear that the materials are being reused under permission of a Creative Commons License. Views, opinions and conclusions expressed in this research article are views, opinions and conclusions of the author(s). and European Journal of Literature, Language and Linguistics Studies shall not be responsible or answerable for any loss, damage or liability caused in relation to/arising out of conflicts of interest, copyright violations and inappropriate or inaccurate use of any kind content related or integrated into the research work. All the published works are meeting the Open Access Publishing requirements and can be freely accessed, shared, modified, distributed and used in educational, commercial and non-commercial purposes under a Creative Commons Attribution 4.0 International License (CC BY 4.0). 